\title{
Probiotic strains for shellfish aquaculture: protection of eastern oyster, Crassostrea virginica, larvae and juveniles againsl bacterial challenge
}

\begin{abstract}
Bacterial pathogens, including several Vibrio spp. and Roseovarius crassostreae, cause severe mortality of larval and juvenile eastern oysters. The introduction of beneficial bacterial isolates in oyster hatcheries and nurseries for the biocontrol of bacterial diseases is a good alternative to the use of antibiotics. The goal of this study was to screen and characterize marine bacterial isolates as potential agents to prevent larval and juvenile mortality by the oyster pathogens Vibrio tubiashii and R. crassostreae. Screening of bacterial isolates from Rhode Island marine organisms and environment using agar-based assay methods for detection of antimicrobial activity against oyster pathogens led to the isolation of candidate probionts Phaeobacter sp. S4 and Bacillus pumilus RI06-95. Pretreatment of larval and juvenile oysters for $24 \mathrm{~h}$ with $102 \mathrm{ï} 106 \mathrm{cfu} / \mathrm{mL}$ Phaeobacter sp. S4 or B. pumilus RI06-95 protected larval oysters against mortality resulting from challenge with R. crassostreae and V. tubiashii (relative percent survival (RPS) range, 9\% $56 \%$ ). These probiotics also protected juvenile oysters against challenge with V. tubiashii (RPS, 37\% $50 \%$ ). Probiotic isolates had no negative impact on oyster survival. Protection conferred to larvae against bacterial challenge was short-lived, lasting for only $24 \mathrm{~h}$ after removal of the probiotics from the incubation water. These results suggest the potential of marine bacterial isolates Phaeobacter sp. S4 and B. pumilus RI06-95 to serve as biocontrol agents to reduce the impact of bacterial pathogens in the culture of Crassostrea virginica.
\end{abstract}

Keyword: Crassostrea virginica; Oyster juveniles; Oyster larvae; Probiotic bacteria; Roseovarius oyster disease; Shellfish hatchery; Shellfish nursery; Vibrio tubiashii; Vibriosis 